\title{
Echinococcosis in Dogs in the Czech Republic
}

\author{
V. SVOBODOVÁ, B. LENSKÁ \\ Department of Parasitology, Faculty of Veterinary Medicine, \\ University of Veterinary and Pharmaceutical Sciences Brno, Czech Republic
}

Received March 6, 2002

Accepted June 19, 2002

Abstract

Svobodová V., B. Lenská: Echinococcosis in Dogs in the Czech Republic. Acta Vet. Brno 2002, 71: 347-350.

In central Europe, foxes are principal definitive hosts of Echinococcus multilocularis. However, dogs may become definitive hosts too, and due to close contact with humans they may be the source of infection. We examined samples of dog faeces from the areas with high density of red foxes. The dogs were rigorously selected on the basis of specific individual history confirming predator habits and a possibility of free movement allowing the dogs to hunt for rodents. Samples of dog faeces were examined by ELISA detecting specific coproantigens Echinococcus spp. (CHEKIT Echinotest, Bommeli, Switzerland). A total of 186 samples of dog faeces were examined with 15 positive cases detected $(8.1 \%)$.

Echinococcus multilocularis, coproantigens, ELISA, zoonosis, prevalence

Parasitic diseases with zoonotic potential present a significant health problem worldwide. Echinococcus multilocularis, a small tapeworm of Taeniidae family, also belongs among zoonotic helminths. Its occurrence is especially linked to the fox as the definitive host. However, dogs and cats may become definitive hosts as well. In particular the animals that may hunt murids and that live in close contact with humans present a considerable risk. Such animals may also become source of the disease for humans.

In the conditions of central Europe red fox (Vulpes vulpes) is the main definitive host of this parasite (Thompson and Eckert 1983; Dubinský et al. 1999). Other definitive hosts may include the dog (Canis familiaris) (Deplazes et al. 1999) and the cat (Felis catus f. domestica) (Deblock et al. 1989; Petavy et al. 1988). Small rodents are becoming intermediate hosts. On the territory of the Czech Republic, they are represented in particular by common vole (Microtus arvalis) (Kolářová 1999). The eggs of E. multilocularis may cause alveolar echinococcosis in humans, which is a dangerous zoonosis. The prevalence of alveolar echinococcosis in the endemic areas of central Europe ranges between 0.03 and 1.2 per 100,000 inhabitants (Eckert and Deplazes 1999).

The objective of the present work was to establish the prevalence of E. multilocularis in dogs that live in and move around the areas with dense population of red foxes.

\section{Materials and Methods}

During the period of 2000 to 2001 samples of faeces were collected from dogs especially from the areas where the occurrence of E. multilocularis in red foxes was reported earlier (Pavlásek 1998; Martínek et al. 2001) or where it was indicated by the data provided by district offices of the State Veterinary Administration. The dogs were selected for the examination strictly on the basis of specific individual history confirming predator habits and a possibility to move around freely and to hunt for rodents. The numbers of samples of dog faeces from different localities with confirmed prevalence of $E$. multilocularis were as follows: 44 samples from a locality with $63.3 \%$ prevalence, 52 samples from another locality also with $63.3 \%$ prevalence, 4 samples from a locality with $6.6 \%$ prevalence, 6 and 39 samples from two distant localities with equally $28.6 \%$ prevalence. Samples were also taken from two localities where the occurrence in red foxes had not been confirmed ( 24 and 5 samples) and from one locality where no examination in red foxes had been carried out (12 samples).

Address for correspondence:

Doc. MVDr. Vlasta Svobodová, CSc.

Department of Parasitology, Faculty of Veterinary Medicine

Deparment of Parasingeg, Fachlly of veteninary Medicine

Palackého 1-3,612 42 Brno, Czech Republic
Phone: +420541562265

Fax: + 420549248841

http://www.vfu.cz/acta-vet/actavet.htm 
The samples of dog faeces were stored at $-18{ }^{\circ} \mathrm{C}$ and $-80{ }^{\circ} \mathrm{C}$ until tested. One $\mathrm{g}$ of every sample was used for investigation. Samples of dog faeces were examined by ELISA for the detection of specific coproantigens of Echinococcus spp. (CHEKIT - Echinotest, Bommeli, Switzerland).

\section{Results}

A total of 186 samples of dog faeces were examined. Coproantigens Echinococcus spp. were detected in 15 samples (8.1\%), 171 samples (91.9\%) were found negative.

The summary of the results of examinations in dogs with breakdown by different areas with various levels of E. multilocularis prevalence in red foxes is presented in Table 1. Topography of different localities with confirmed echinococcosis in red foxes and dogs is depicted in Fig. 1.

Table 1

Comparison of the values of echinococcosis prevalence in red foxes and dogs

\begin{tabular}{|c|c|c|c|c|c|}
\hline $\begin{array}{c}\text { Prevalence in red } \\
\text { foxes in the area }\end{array}$ & \multicolumn{4}{|c|}{ Prevalence in dogs in the area } \\
\hline$\%$ & $\begin{array}{c}\text { Total } \\
\text { Number }\end{array}$ & $\begin{array}{c}\text { Number of } \\
\text { positive cases }\end{array}$ & $\begin{array}{c}\text { Percentage of } \\
\text { positive cases }\end{array}$ & $\begin{array}{c}\text { Number of } \\
\text { negative cases }\end{array}$ & $\begin{array}{c}\text { Percentage of } \\
\text { negative cases }\end{array}$ \\
\hline $63.3^{* *}$ & 44 & 3 & 6.8 & 41 & 93.2 \\
\hline $63.3^{* *}$ & 52 & 3 & 5.8 & 49 & 94.2 \\
\hline $6.6^{*}$ & 4 & 1 & 25 & 3 & 75 \\
\hline $28.6^{*}$ & 6 & 1 & 16.7 & 5 & 83.3 \\
\hline $28.6^{*}$ & 39 & 4 & 10.3 & 35 & 89.7 \\
\hline 0 & 24 & 3 & 12.5 & 21 & 87.5 \\
\hline 0 & 5 & 0 & 0 & 5 & 100 \\
\hline No examined & 12 & 0 & 0 & 12 & 100 \\
\hline Grand total & 186 & 15 & 8.1 & 171 & 91.9 \\
\hline
\end{tabular}

*Pavlásek 1998; **Martínek et al. 2001

Fig. 1. Topography of the occurrence of echinococcosis in red foxes and dogs in the Czech Republic

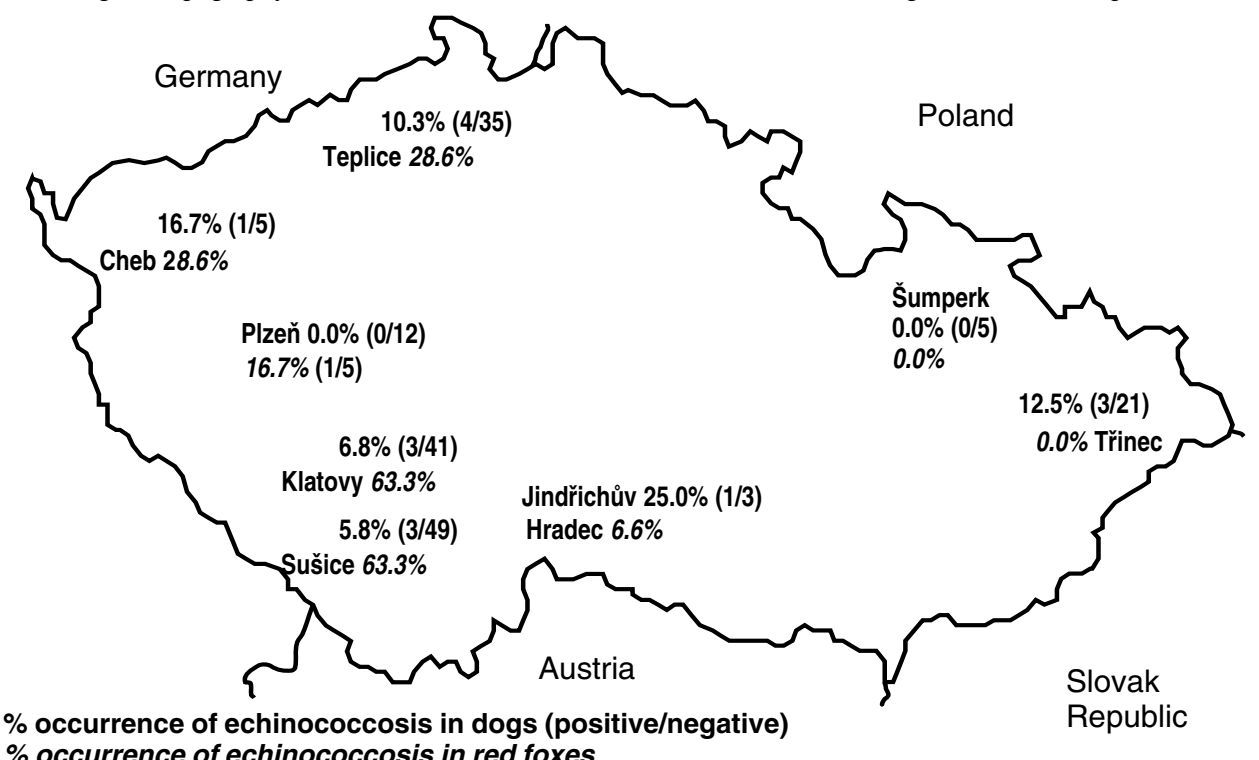

$\%$ occurrence of echinococcosis in red foxes 


\section{Discussion}

The overview of epidemiological situation in the Czech Republic was prepared by Kolářová (1999). The occurrence is known in particular in foxes as the principal definitive hosts of Echinococcus multilocularis. Average prevalence was determined at $19.7 \%$ on the basis of monitoring during the period of 1994-1999, when intestines of red foxes which had been shot and found negative for rabies were examined (Pavlásek 1998). In some localities, especially in southern Bohemia, much higher values of prevalence at $70.6 \%$ (Pavlásek 1998) and 63.3\% (Martínek et al. 2001) were found. Dogs and cats were confirmed as facultative definitive hosts by Ča da et al. (1999), who diagnosed post mortem the infection in a kitten, and by Martínek et al. (1999), who demonstrated presence of $E$. multilocularis in one case $(1.8 \%)$ out of 55 samples of dog faeces collected on the streets of a small village in southern Bohemia.

There are not much data available on the occurrence of echinococcosis in dogs, because the post mortem diagnosis, which is normally used in red foxes, cannot be applied in dogs in large scale. Therefore mostly intravital methods are used. Average prevalence detected in our group of dogs was $8.1 \%$. Positive samples of dog faeces originated also from the localities, where no occurrence of E. multilocularis was confirmed during recent years. It can be expected that at the level of $12.5 \%$ of positive samples of dog faeces the infection in red foxes does not occur at present. The prevalence of echinococcosis in dogs in the Czech Republic seems to be at a higher level, because for instance in Switzerland coproantigens were detected by ELISA in dogs in $0.3 \%$ only (Deplazes et al. 1999). Higher values of prevalence, diagnosed in dogs in the Czech Republic, correspond to our strategy of sampling, since the animals originated from the areas where the density of red foxes was high. Moreover, the owners reported that the animals selected had a possibility to move freely and to hunt for rodents. A similar situation with higher occurrence of echinococcosis in dogs in an endemic locality in Switzerland was described by Deplaze s et al. (1998), who detected coproantigens in $9 \%$ of dogs on farms. Although the statement of positive detection in the areas where only low numbers of samples were obtained, may not be completely objective, it certainly shows that echinococcosis is not rare in the given locality. If the group of dogs sampled had been randomly selected from different parts of the country including large cities, the number of positive cases would be probably lower.

The detection of coproantigens specific for Echinococcus spp. by ELISA is genusspecific. However, on the basis of epidemiological situation in the Czech Republic and with regard to characteristic features of the group of dogs selected we assume that the agent was mainly Echinococcus multilocularis. Compared with SCT (Intestinal Sedimentation and Counting Technique, Rausch et al. 1990), the method used has a sensitivity of $80 \%$ and a specificity of 95-99\% (Deplazes and Eckert 1996). Therefore we continue to store positive samples for PCR examination for the purpose of final diagnosis.

Although the occurrence of E. multilocularis in the definite hosts is not rare at all, the disease in humans develops only seldom (Kreidl et al. 1998; Auer and Aspöck 2001). A single case of alveolar echinococcosis was reported in humans in the Czech Republic (Šlais et al. 1979). Nevertheless the danger of infection must be prevented. The dogs that may be exposed should be dewormed on a regular basis every three months with praziquantel or epsiprantel (Deplazes and Eckert 2001).

\section{Výskyt echinokokózy psů v České republice}

Echinokokóza patří k nebezpečným zoonózám parazitárního původu. Hlavním definitivním hostitelem Echinococcus multilocularis ve střední Evropě jsou lišky, ale mohou jím být i psi, kteří vzhledem $\mathrm{k}$ těsnému kontaktu představují potenciální zdroj 
infekce pro člověka. Vyšetřovali jsme vzorky trusu psů žijících v oblastech s hojným výskytem lišek. Psi byli vybíráni striktně na základě cílené anamnézy potvrzující predátorské sklony a možnost volného pohybu spojeného s lovem hlodavcủ. Vzorky trusu psů byly vyšetřeny metodou ELISA k detekci specifických koproantigenů Echinococcus spp. s využitím setu CHEKIT - Echinotest firmy Bommeli, Švýcarsko. Z celkového počtu 186 vzorků trusu psů bylo 15 pozitivních $(8,1 \%)$. I když k rozvoji onemocnění u člověka dochází zřídka, je třeba nebezpečí předcházet a u psů patřících do exponované skupiny provádět cíleně pravidelnou dehelmintizaci.

\section{Acknowledgement}

This study was supported by the Research Grant of the Ministry of Education of the Czech Republic No.1267/2001.

\section{References}

AUER, H, ASPÖCK, H 2001: Human alveolar echinococcosis and cystic echinococcosis in Austria: The recent epidemiological situation. Helminthologia 38: 3-14

ČADA, F, MARTÍNEK, K, KOLÁŘOVÁ, L 1999: Domestic cat (Felis catus f. dom.) as the final host of Echinococcus multilocularis tapeworms. Veterinárství 49: 2-3

DEBLOCK, S, PROST, C, WALBAUM, S, PETAVY, AF 1989: Echinococcus multilocularis: a rare cestode of the domestic cat in France. Int J Parasitol 6: 687-688

DEPLAZES, P, ALTHER, P, TANNER, I, THOMPSON, RCA, ECKERT, J 1999: Echinococcus multilocularis coproantigen detection by enzyme-linked immunosorbent assay in fox, dog and cat populations. J Parasitol $\mathbf{8 5}$ : $115-121$

DEPLAZER, P, ECKERT, J 2001: Veterinary aspects of alveolar echinococcosis - a zoonosis of public health significance. Vet Parasitol 98: 65-87

DEPLAZES, P, ECKERT, J, 1996: Diagnosis of the Echinococcus multilocularis infection in final hosts. Appl Parasitol 37: 245-252

DEPLAZES, P, HOFER, S, GLOOR, S, GOTTSTEIN, B, ECKERT, J 1998: Urbaner Zyklus von Echinococcus multilocularis und Untersuchungen zur epidemiologischen Rolle von Hunden und Katzen als Endwirte. Abstracts, 18. Tagung der Deutschen Gesselschaft f. Parasitologie, Dresden

DUBINSKÝ, P, SVOBODOVÁ, V., TURČEKOVÁ, L., LITERÁK, I., MARTÍNEK, K, REITEROVÁ, K. KOLÁŘOVÁ, L, KLIMEŠ, J, MRLÍK, V 1999: Echinococcus multilocularis in the Slovak Republic: The first record in red foxes (Vulpes vulpes). Helminthologia 36: 105-110

ECKERT, J., DEPLAZES, P. 1999: Alveolar Echinococcosis in humans: The Current Situation in Central Europe and the Need for Countermeasures. Parasitol Today 15: 315-319

KOLÁŘOVÁ L. 1999: Echinococcus multilocularis: new epidemiological insights in Central and Eastern Europe. Helminthologia 36: 185-191

KREIDL, P, ALLERBERGER, F, JUDMAIER, J, AUER, H, ASPÖCK, H, HALL, AJ 1998: Domestic Pets as Risk Factors for Alveolar Hydatid Disease in Austria. Am J Epidemiol 147: 978-981

MARTÍNEK, K, ČERVENY, J, KOLÁŘOVÁ, L, STRNADOVÁ, L, 1999: Occurrence of Echinococcus multilocularis in carnivora in the district Klatovy (West Bohemia). Helminthologia 36: 132

MARTÍNEK, K, KOLÁŘOVÁ, L, ČERVENÝ, J 2001: Echinococcus multilocularis in carnivores from the Klatovy district of the Czech Republic. J Helminthol 75: 61-66

PAVLÁSEK, I. 1998: Actual situation in the occurence of Echinococcus multilocularis in red foxes in Europe and in the Czech Republic. Rem-Klin Mikrobiol 2: 233-240

PETAVY, AF, PROST, C, GEVREY, J, GILOT, B, DEBLOCK, S: 1988: Infestation naturelle du chat domestique (Felis catus L.) par Echinococcus multilocularis Leucart, 1863 (Cestoda): premier cas en France décelé en zone peri-urbaine. CR Acad Sci III Vie 307: 553-556

RAUSCH, RL, FAY, FH, WILLIAMSON, FSL 1990: The ecology of Echinococcus multilocularis (Cestoda: Taeniidae) on St. Lawrence Island, Alaska. II. Helminth populations in the definitive hosts. Annales Parasitol Hum Comp 65: 131-140

ŠLAIS, J, MÁDLE, A, VANKA, K, JELÍNEK, F, ČERNÍK, V, PRŮCHOVÁ, M, JINDRA, J 1979: Alveolar hydatidosis (echinococcosis) diagnosed by liver puncture biopsy. Časopis lékařŭ českých 118: 472-475

THOMPSON RCA, ECKERT J 1983: Observation on Echinococcus multilocularis in the definitive host. Z Parasitenkde 69: 336-34 